\title{
Comparison of Reading Performance in Students with Developmental Dyslexia by $\operatorname{Sex}^{1}$
}

\author{
Adriana Marques de Oliveira ${ }^{2}$ \\ Universidade Estadual Paulista, \\ Marília-SP, Brazil
}

\author{
Giseli Donadon Germano \\ Universidade Estadual Paulista, \\ Marília-SP, Brazil
}

\author{
Simone Aparecida Capellini \\ Universidade Estadual Paulista, \\ Marilia-SP, Brazil
}

\begin{abstract}
This study aims to compare the performance of male and female dyslexic students in tests of reading words and pseudowords, and comprehension of sentences and texts. The participants were forty-eight students with dyslexia, attending 3rd grade to 5 th grade of elementary school (age range 8 to 12 years old), from public and private schools, divided into: GI - 14 girls and GII - 34 boys. The researchers applied tests of Reading process assessment: reading of words, reading of pseudowords, comprehension of sentences, and comprehension of texts. The results showed evidence of difference by sex in reading of low frequency words and sentence comprehension. It was concluded that the discussion on the difference between dyslexic students by sex could be relevant in the educational context, as among the five variables, two provided information for promoting further discussion on the subject, highlighting the importance of further studies.
\end{abstract}

Keywords: learning, reading, evaluation, dyslexia, sex

\section{Comparação por Sexo do Desempenho em Leitura de Escolares com Dislexia do Desenvolvimento}

\begin{abstract}
Resumo: Este estudo objetiva comparar o desempenho dos escolares com dislexia entre os sexos feminino e masculino em provas de leitura de palavras e pseudopalavras, de compreensão de orações e textos. Participaram 48 escolares com dislexia do $3^{\circ}$ ao $5^{\circ}$ ano do Ensino Fundamental ( 8 a 12 anos de idade) de escola pública e particular divididos em: GI - 14 meninas e GII - 34 meninos. Foram aplicadas provas de avaliação de leitura de palavras e pseudopalavras, compreensão de orações e textos, das Provas de avaliação dos processos de leitura. Os resultados indicaram evidência de diferença por sexo nas provas de leitura de palavras de baixa frequência e compreensão de orações. Concluiu-se que a discussão sobre a diferença entre os escolares com dislexia por sexo pode ser relevante no contexto educacional, pois dentre as cinco variáveis estudadas, duas forneceram informações para levantar maior discussão sobre o tema, destacando a importância de mais estudos.
\end{abstract}

Palavras-chave: aprendizagem, leitura, avaliação, dislexia, sexo

\section{Comparación por Sexo del Desempeño en Lectura de los Estudiantes con Dislexia del Desarrollo}

\begin{abstract}
Resumen: Este estudio tuvo por objetivo comparar el desempeño de los estudiantes con dislexia entre los sexos femenino y masculino en las pruebas de lectura y comprensión lectora. Participaron 48 estudiantes con dislexia del $3^{\circ}$ al $5^{\circ}$ grado de la Enseñanza Fundamental ( 8 a 12 años de edad) de escuelas pública y privada, divididos en: GI - 14 niñas y GII - 34 niños. Fueron aplicadas pruebas de evaluación de lectura de palabras y pseudopalavras, comprensión de oraciones y textos, de las Pruebas de Evaluación de los procesos lectores. Los resultados indican evidencia de diferencia por sexo en las pruebas de lectura de palabras de baja frecuencia y comprensión de oraciones. Se concluyó que la discusión acerca de la diferencia entre los estudiantes con dislexia por sexo puede ser relevante en el contexto educativo, pues de las cinco variables estudiadas, dos proporcionan informaciones para alzar discusiones adicionales sobre el tema, destacando la importancia de mayores estudios.
\end{abstract}

Palabras clave: aprendizaje, lectura, evaluación, dislexia, sexo

Brazilian Portuguese is a language which follows the alphabetical writing system, which requires the child to make the association between an auditory phoneme component and a visual grapheme component. In order to understand this alphabetical

\footnotetext{
${ }^{1}$ Paper deriving from the scientific initiation project of the first author, under the supervision of the third author and with the cooperation of the second author, carried out at the Laboratório de Investigação dos Desvios da Aprendizagem - LIDA of the Universidade Estadual Paulista - FFC/UNESP. Support: São Paulo Research Foundation (FAPESP, Grant \# nº 06/60016-4). ${ }^{2}$ Correspondence address:

Adriana Marques de Oliveira. Departamento de Fonoaudiologia, Avenida Hygino Muzzi Filho, $\mathrm{n}^{\circ}$ 737, Mirante. CEP 17.525-000. Marília-SP, Brazil. E-mail:adrianamarques@marilia.unesp.br
}

principle, three steps are necessary: (1) to segment the spoken language into distinct units, (2) to understand that these units are repeated in different spoken words, and (3) to know the rules of correspondence between graphemes and phonemes. The first two steps are part of phonological processing, which makes them essential processes in the development of reading and writing (Germano \& Capellini, 2011, 2015; Veuillet, Magnan, Ecalle, Thai-Van, \& Collet, 2007).

The system of writing in Portuguese is characterized by its orthographic transparency, that is, by its regularity, with each phoneme corresponding to one and only one grapheme, and vice versa; and by its orthographic opacity, that is, by 
its irregularities, with graphemes which correspond to more than one phoneme, and with phonemes which correspond to various graphemes (Germano \& Capellini, 2011, 2015).

In order to explain the model of recognition of words in reading, the authors adopted the dual route model (Ellis \& Young, 1988). In this model, the reader can undertake reading through the use of two routes, described as phonological and lexical. Reading by the phonological route depends on the use of recognition of the rules of conversion between grapheme and phoneme so that the word's pronunciation may be constructed. What is created, therefore, is a phonological code, identified by the auditory system of word recognition, which thus makes it possible to access its meaning. Reading by the lexical route depends on the recognition of a previouslyacquired and memorized word in the visual system of word recognition, and on the retrieval of its meaning and its pronunciation through direct addressing to the lexicon, this pronunciation being obtained as a whole (Capellini, Oliveira, \& Cuetos, 2012; Germano, Pinheiro, \& Cunha, 2010; Kim, Petscher, Foorman, \& Zhou, 2010; Lukasova, Barbosa, \& Macedo, 2009; Nation \& Cocksey, 2009; Pinheiro, 2006; Pinheiro, Lúcio, \& Silva, 2008; Vellutino \& Fletcher, 2013).

According to this model, both routes are acquired during the learning of reading. This process, however, does not take place adequately in students with developmental dyslexia, with studies mentioning impairment in both the phonological and lexical routes (Peterson, Pennington, Olson, \& Wadsworth, 2014).

Developmental dyslexia is defined as a developmental disorder characterized by significant and specific difficulties in reading and writing (Leach, Scarborough, \& Rescorla, 2003; Vellutino \& Fletcher, 2013). The difficulties in reading and writing found in the students with dyslexia are characterized as failures to acquire basic skills (difficulties in decoding words), complex skills (difficulties in understanding reading) and orthographic skills (Fletcher, Lyons, Fuchs, \& Barnes, 2009; Leach et al., 2003; Nation \& Cocksey, 2009; Vellutino \& Fletcher, 2013).

Students with dyslexia present compromise in phonological representations, which makes it difficult for them to acquire skills such as phonological awareness, alphabetical mapping and phonological decoding - along with skills such as orthographic awareness. The lack of skill in decoding can be the cause of other problems which contribute to difficulties in acquiring reading, in particular those of storing and retrieving words in the spoken language (Fletcher et al., 2009; Snowling, 2004; Vellutino et al., 1996; Vellutino \& Fletcher, 2013; Vellutino, Scanlon, \& Tanzman, 1994).

In students with developmental dyslexia, the component of phonological decoding is altered, which entails shortcomings in the processing of reading, as this depends on the use of knowledge of the rules of conversion between graphemes and phonemes, in order to construct the reading of the word. This skill, which is essential for learning reading and writing, has been a topic of discussion among researchers, both in education and in health (Batista, Cunha, \& Germano, 2011; Cunha \& Capellini, 2009, 2010; Desroches, Joanisse, \& Robertson, 2006).
The difficulties relating to lexical skills, such as the identification of words and orthography, along with related difficulties, such as phonological awareness, observed in students with dyslexia as they begin to develop their reading skills, continue to be evident through to adulthood (Hatcher, Snowling, \& Griffiths, 2002; Vellutino \& Fletcher, 2013).

As dyslexia has a genetic origin, and some difficulties may be observed in oral skills prior to gaining literacy in activities involving phonological awareness, this being characterized as an indicator of risk for dyslexia (Capellini, Cerqueira César, \& Germano, 2015; Germano \& Capellini, 2011, 2015), studies have been undertaken considering family history and prevalence of males to females in reading difficulty.

The effect of sex on the incidence of dyslexia has been widely debated in the international literature since the 1980 s (Finucci \& Childs, 1981). The variable of sex seems to be critical for the investigation of linguistic competences and of reading in general - in particular for dyslexia. Some studies suggest that dyslexia has been described as being from three to four times more prevalent in male students than among female students. In addition to this, this epidemiological debate suggests that the relevant differences between the sexes seem to appear in underlying neuroanatomical substrates. Postmortem analyses have identified cortical ectopias in dyslexic brains. These abnormalities' pattern seems to be different in male and female dyslexics (Galaburda \& Kemper, 1979; Lambe, 1999).

In functional magnetic resonance imaging studies, Pugh et al. (1996) ascertained patterns of activation during reading, the results indicating that for female dyslexics, cerebral activation was focal, anterior, and predominantly in the left hemisphere when compared with male dyslexics. Furthermore, this study's findings also indicated that in phonological processing activities, female dyslexics undertook bilateral activation, whereas the same was not ascertained in male dyslexics.

On the other hand, recent studies (Hawke, Olson, Willcut, Wadsworth, \& DeFries, 2009) have mentioned that the proportions between male and female students with learning difficulties vary depending on the study method used - that is, whether the sample is identified through methods involving clinical reference or study recruitment, in spite of a greater incidence of men with shortcomings in reading being found with each method. For these authors, some biological and environmental hypotheses are proposed in the attempt to explain this difference based on sex; namely, X-chromosome inheritance (Symmes \& Rapoport, 1972); functional differences in the brain, due to differential exposure, or to sensitivity to hormones (Geschwind, 1981; Nass, 1993; Tallal \& Fitch, 1993); immunological factors, sexual imprinting, perinatal complications and differential resilience to neural insults (Liederman, Kantrowitz, \& Flannery, 2005). In addition to these factors, there are studies which indicate that female children may be less sensitive to environmental factors such as, for example, methods of teaching and socioeconomic level (Geschwind, 1981; Hawke et al., 2009), as well as genetic influences which may contribute to performance in reading tasks, when compared with male children (DeFries \& Gillis, 1993; Stevenson, 1992). 
Genetic studies have been used to explore the link between sex and dyslexia in greater depth (Wong et al., 2012). For instance, Harlaar, Spinath, Dale and Plomin (2005) identified cases that were more heavily-affected among males. In contrast, Hawke et al. (2009) found no evidence of different etiology for reading difficulties due to sex. The authors showed, furthermore, that the difference between the mean scores of male and female children was not very significant. Instead of this, they observed that the variance in the performance of reading was significantly greater for boys in groups with moderate and severe impairment in reading. The male: female proportion, therefore, may be seen in terms of severity of difficulty in the performance of reading, even when the populations' means are exactly equal. Moreover, Donfrancesco et al. (2010) showed that male children have a greater risk of dyslexia (probability rate $=2.16$ ). Additionally, in a sample which was representative of Italian children, the effects of sex interacted with the age at which the child entered school, and with time of year of birth. In that study, the joint effects of sex (in the case of a male student) and age prior to entering school were significantly associated with the presence of dyslexia. Wong et al. (2012) also ascertained a prevalence of 1.59:1 (male: female) in the Chinese population.

In the light of the above, although various international studies have been mentioned, studies comparing the variable of sex with performance in reading in students with dyslexia are extremely rare in the Brazilian literature. The hypothesis raised here is that evidence will be found of difference between male and female students in tests assessing the reading of words and pseudowords, and the understanding of sentences and texts.

Studies in other populations, speaking other languages, have been undertaken internationally (Italian, English and Chinese), with the same not being ascertained in the population which speaks Brazilian Portuguese. As a result, it is important to investigate whether the variable of sex increases the risk of dyslexia, or influences the effects of other cognitive and linguistic factors. This study's objective, therefore, was to compare the performance of male and female students with dyslexia in tests of reading words and pseudowords and understanding sentences and texts.

\section{Participants}

\section{Method}

This study's participants were 48 students with interdisciplinary diagnosis of developmental dyslexia, in the age range from 8 to 12 years old, from the third to the fifth year of schools in Primary Education I (EFI, in Portuguese), from both the public and private networks, from a city in the non-metropolitan area of the state of São Paulo. The sample was selected by convenience, in accordance with availability of, and authorization of those responsible for, the students who met the criteria of interdisciplinary diagnosis of developmental dyslexia (Germano \& Capellini, 2011, 2015), diagnosed as such by the multidisciplinary team in the Investigation of Learning Disabilities Laboratory, at the Universidade Estadual Paulista (LIDA - UNESP). The students were divided into two (2) groups, according to sex, these being:

(1) Group I (GI): 14 female students, with an interdisciplinary diagnosis of developmental dyslexia, these being three students from the third year of EFI (aged between 7:00 and 8:11 years old), four students from the fourth year of EFI (aged between 8:00 and 9:11 years old) and seven students from the fifth year of EFI (aged between 10:00 and 11:11 years old);

(2) Group II (GII): 34 male students with an interdisciplinary diagnosis of developmental dyslexia, these being eight students from the third year of EFI (aged between 7:00 and 8:11 years old), nine students from the fourth year of EFI (aged between 8:00 and 9:11 years old) and 17 students from the fifth year of EFI (aged between 10:00 and 11:11 years old).

The diagnosis was undertaken in accordance with criteria cited in the literature (Germano \& Capellini, 2011, 2015). The students were considered to be dyslexic when they presented the following criteria in a situation of interdisciplinary evaluation: changes regarding static balance and appendicular coordination, motor persistence, dynamic balance, torso-limb coordination and sensitivity in the evolutionary neurological examination; normal cognitive level, changes in memory in the neuropsychological battery of questions, changes in phonological awareness, oral reading speed below that expected for age and educational level, performance considered to be inferior in tests of reading isolated words and sequential texts, performance below that expected in tests of writing under dictation and reading comprehension of the text read considered to be partial.

\section{Instruments}

The Evaluation of Processes of Reading (PROLEC) (Capellini et al., 2012) is a battery of assessment tests, based in the criteria and rules of the development of reading, which assess the different processes and sub-processes which negatively influence reading. Its evaluations range from the process of identifying letters through to the semantic process, in Brazilian students from the second to the fifth year of Primary Education, thus allowing the identification of cases of difficulties, and which processes are responsible for these difficulties. Its adaptation and checking were undertaken with a sample made up of 401 students (201 boys and 200 girls) from the second to the fifth school years of Primary Education; 102 were from the second year, 98 from the third year, 98 from the fourth year and 103 from the fifth school year.

This instrument's accuracy was checked using the Cronbach alpha coefficient. The alpha value obtained with this sample of subjects was 0.94, indicating good internal consistency. The instrument's validity was sought in the Spanish version, through a content validity study; correlation was obtained between the global scores in the battery in the opinion of a group of professors who scored each student's reading skill on a scale from 1 to 10 . The correlation was 0.53 , which means that this test genuinely does measure the students' reading skills. The PROLEC tests are applied 
individually. The following tests were selected from the tests which make up the PROLEC battery of tests:

Test for Reading Words and Pseudowords: the objective is to analyze the degree of development that the student has achieved, through the use of the phonological and lexical routes for reading. For this, it used 60 stimuli, divided into 20 high-frequency words, 20 low-frequency words, and 20 pseudowords, subdivided into six categories: namely, 10 short high-frequency words, 10 long high-frequency words, 10 short low-frequency words, 10 long low-frequency words, 10 short pseudowords and 10 long pseudowords. The score varies from 0 to 60 in the total score, and from 0 to 20 for the high-frequency, low-frequency and pseudowords.

Sentence Understanding Test: the objective is to assess whether the student is able to extract the meaning from simple sentences, without requiring, therefore, the intervention of memory or of mental schemes. The test is made up of 12 sentences (some accompanied by pictures) which express a simple order to be executed by the student. The first three sentences ask the student to carry out simple orders; the following three, to make simple drawings; the following three, to undertake tasks regarding the drawings presented; and the final three, to recognize which drawing corresponds to the sentence presented. The score varies from 0 to 12 .

Text Comprehension Test: this makes it possible to investigate whether the student is able to extract the meaning and integrate it with his or her knowledge. This test requires the intervention of memory and mental schemes and is made up of four (4) texts, of which two (2) are of the narrative type, and two (2) expository. Each text contains questions, two of which are literal and two of which are inferential, totaling 16 questions. The score ranges from 0 to 16 .

The students' performance in each one of the tests was evaluated through the score in each process, according to the manual for application and correction of the procedure. The answers were recorded were made in the answer booklet in the following way: if the response given by the student was correct, a circle was drawn around the number 1; if the response was incorrect, the number 0 was circled; and in the event of error, in the space corresponding to the item, the response given by the student was noted. One point, therefore, was attributed for each correct response, with decimal scores not being accepted.

\section{Procedures}

Data collection. application of the tests for reading words and non-words, comprehension of sentences and the text, took place in this order of presentation, in accordance with the advice for the procedure. The tests were applied individually, with a mean duration of 20 minutes, in a single session. The evaluations were undertaken by two speech and language therapists who had been trained to administer the PROLEC tests. The procedure was applied after the conclusion of the interdisciplinary diagnosis.

Data analysis. The SPSS program (Statistical Package for the Social Sciences), version 21.0, was used for the statistical analysis, based on the number of correct answers for each test, presented by the groups GI and GII. A level of significance of $5 \%(\mathrm{p}<0.05)$ was adopted for the application of the statistical tests. Descriptive analysis of the data was undertaken, obtaining the mean and median scores, the 25 th percentile scores, the 75 th percentile scores, minimum and maximum values, and standard deviation. For the comparison between the groups, the Mann-Whitney test was used, with the aim of ascertaining possible differences between the performances of the students from GI and GII.

\section{Ethical Considerations}

This study was submitted to, and approved by, the institution's Research Ethics Committee under protocol N. 182-2011. Those responsible for the students signed the terms of free and informed consent, and the terms of consent were signed by the students evaluated.

\section{Results}

Table 1 presents the application of the Mann-Whitney test, with the aim of ascertaining possible differences between the performances of the female dyslexic students (GI) and the male dyslexic students (GII), in the PROLEC tests of reading high and low-frequency words and pseudowords, and comprehension of sentences and texts, in students with dyslexia.

By mean score, the test of reading high-frequency words obtained the highest score by the students with dyslexia $(M=$ $14, S D=6.582$ ), followed by tests of reading low frequency words $(M=12.46, S D=6.565)$, pseudowords $(M=10.60, S D$ $=6.503)$, understanding of sentences $(\mathrm{M}=7.90, \mathrm{SD}=4.896)$ and texts $(M=7.04, S D=5.757)$.

Evidence of difference in performance in the RP_LF tests $(p$ value $=0.018)$ and SC tests $(p$ value $=0.047)$ was found when the GI and GII groups were compared. For the female students (GII), in the RP_LF test, the mean had a value of 15.71 , and the standard deviation was $(S D=$ $4.983)$. In relation to the percentiles, it was observed that $25 \%$ of the students from GI obtained a score of 14.50 for this test (25th percentile). In the 50th percentile (or median), it is noted that $50 \%$ of the students obtained a score of 17.50 .

In the same test, the male students $(M=11.12, S D=$ 6.727) had worse performance than the female students $(M$ $=15.71, S D=4.983)$. In relation to the percentiles, it was noted that $25 \%$ of the students from GI obtained scores of 3.75; for the 50th percentile or median, 13.00, and for the 75th percentile, the value was 16.25 . The minimum and maximum scores were zero (minimum value) through to 20 (maximum value), obtained by some students.

In relation to the $\mathrm{SC}$ test, the female students (GII) presented a mean score with the value of 10.29 , and a standard deviation with a value of 6.503. Regarding the value of the median, it is noted that for GI, in this test, $50 \%$ of the population achieved the maximum value for the test (12 correct answers). 
Table 1

Description and comparison of the performance of students from groups GI and GII in the PROLEC tests of reading and of words of high and low frequency, pseudowords, sentence comprehension and comprehension of texts

\begin{tabular}{|c|c|c|c|c|c|c|c|c|c|}
\hline Variable & Group & Mean & Standard-deviation & Percentile 25 & Median & Percentile 75 & Minimum & Maximum & $p$ Value \\
\hline \multirow{3}{*}{ RP_HF } & I & 16.07 & 5.757 & 14.50 & 18.50 & 20.00 & 0 & 20 & \multirow{3}{*}{0.080} \\
\hline & II & 13.15 & 6.787 & 8.00 & 16.50 & 19.00 & 0 & 20 & \\
\hline & Total & 14 & 6.582 & 10 & 17 & 19 & 0 & 20 & \\
\hline \multirow{3}{*}{ RP_LF } & I & 15.71 & 4.983 & 14.50 & 17.50 & 19.00 & 0 & 19 & \multirow{3}{*}{$0.018^{*}$} \\
\hline & II & 11.12 & 6.727 & 3.75 & 13 & 16.25 & 0 & 20 & \\
\hline & Total & 12.46 & 6.565 & 9.25 & 15 & 18 & 0 & 20 & \\
\hline \multirow{3}{*}{ RPW } & I & 13.29 & 5.915 & 7 & 16 & 18 & 0 & 19 & \multirow{3}{*}{0.070} \\
\hline & II & 9.50 & 6.491 & 5 & 9.50 & 15.50 & 0 & 20 & \\
\hline & Total & 10.60 & 6.503 & 6 & 10 & 17 & 0 & 20 & \\
\hline \multirow{2}{*}{$\mathrm{SC}$} & I & 10.29 & 3.221 & 9 & 12 & 12 & 0 & 12 & \multirow{2}{*}{$0.047 *$} \\
\hline & II & 6.91 & 5.160 & 0.00 & 8 & 12 & 0 & 12 & \\
\hline \multirow{4}{*}{$\mathrm{TC}$} & Total & 7.90 & 4.896 & 3.50 & 11 & 12 & 0 & 12 & \multirow{4}{*}{0.218} \\
\hline & I & 9 & 4.438 & 7.75 & 9.50 & 12.25 & 0 & 15 & \\
\hline & II & 6.24 & 6.095 & 0.00 & 7 & 12 & 0 & 16 & \\
\hline & Total & 7.04 & 5.757 & 0.00 & 8.50 & 12 & 0 & 16 & \\
\hline
\end{tabular}

Note.* statistically significant; RP_HF: reading of frequent words, RP_LF: reading of infrequent words, RPW: reading of pseudowords, TC: Text comprehension, SC: Sentence comprehension

Regarding the male students (GII), these presented a mean with a value of 6.91 , and standard deviation with a value of 5.160. In relation to the percentiles, for the 25 th percentile, the value was 0.00 ; for the 50th percentile, or median, the value was 8.00 ; and for the 75 th percentile, the value was 12 . For this group, it was observed that - in this test $-50 \%$ of the population obtained the maximum value for the test (eight correct answers).

\section{Discussion}

In this study, the dyslexic students performed best in reading the high-frequency words, followed by the lowfrequency words and pseudowords. This is explained by the fact that they undertook the reading of these words using the lexical route, which benefits from the frequency of the occurrence of the words in the language, as the greater the frequency, the more established its lexical representation is, and the easier it is to retrieve it from the lexicon (Capellini et al., 2012; Cunha \& Capellini, 2009, 2010; Germano et al., 2010; Lukasova et al., 2009). As the majority of the dyslexic students have difficulty in the phonological processing of words (Vellutino \& Fletcher, 2013), it is observed that the mean performance in the tests reduces as the complexity increases, as observed in the reading of low-frequency words and pseudowords, and in comprehension of sentences and texts, as difficulties in the skill of decoding may be accompanied by difficulties in comprehension of the language, knowledge of the vocabulary, and syntactic competence, which directly affects the students' performance in the tests focusing on comprehension of sentences and texts (Leach et al., 2003; Vellutino \& Fletcher, 2013).

On comparing this study's results with the mean presented in the Prolec procedure (Capellini et al., 2012), in 310 which the students' mean score in the guidelines for the RP HF test for students of the second to the fifth school year ranges from 19.09 to 19.49 for RP_LF (17.94 to 19.21), RPW (17.73 to 19.33$)$, SC (10.78 to 19.33 ) and TC (9.83 to 14.01), note that the mean performance for dyslexic students, regardless of sex, is below that expected for the reference population. In the study undertaken by Oliveira, Cardoso and Capellini (2012), in which the authors compared the performance of students with dyslexia, students with learning disorders and students with good academic performance, it may be observed that the students with dyslexia perform worse than students considered to have good academic performance.

On comparing the results of the present study with the study of Oliveira et al. (2012), it may be observed that the means in these tests were very close, with the exception of the TC test, in which the mean was 5.65, and in this work, was 7.04. When the mean of the students with good academic performance from the third to the fifth year of school is checked, one can see that the mean score resembles that of the reference population (Capellini et al., 2012): RP_HF 19.90, RP_LF 18.75, RPW 17.80, SC 11.85 and TC 13.55.

As seen in the literature, the phonological mediation is altered among students with dyslexia, which entails difficulties in reading comprehension (Leach et al., 2003; Vellutino \& Fletcher, 2013), as difficulty using the skill of decoding impairs fluent reading and, consequently, comprehension of the read material. The students who recognize the words automatically and with the greatest speed can direct more attention to the comprehension than to decoding the words (Capellini et al., 2012; Cunha \& Capellini, 2009; Germano \& Capellini, 2008; Lukasova et al., 2009; O’Connor, Swanson, \& Geraghty, 2010; Piasta \& Wagner, 2010). 
The process of decoding contributes to forming the orthographic representation of the word, allowing it to be read by the lexical route (Capellini et al., 2012; Cunha \& Capellini, 2009, 2010). Phonological skill correlates with processing a sentence during reading, as it interferes directly in the grammatical and semantic structuration of the word in the phrase and text (Fletcher et al., 2009; Nation \& Cocksey, 2009). It is emphasized that up to the time of writing, Brazilian studies have not been found comparing performance in reading among students with dyslexia, by sex; therefore, only discussion was undertaken, based on the specific characteristics of the students with dyslexia, without distinction by sex.

Regarding the comparison between the sexes of students with dyslexia, evidence was ascertained of differences in the RP $\mathrm{LF}$ and $\mathrm{SC}$ tests, that is, the groups differed in the tests of reading low-frequency words (RP_LF) and in sentence comprehension (SC). Based on the score obtained, it was possible to observe superior performance from the female students (GI) in comparison with the male students (GII). Analysis of the standard deviation shows that the students from GII show greater variability in their responses than do the students from GI, which suggests greater heterogeneity in the responses (greater occurrence of errors).

According to the present study's results, female students presented superior performance in tests based on the reading of low-frequency words and sentence comprehension, suggesting that these present better phonological representation, promoting lexical-semantic access, which permits better comprehension of the sentences. The male students, on the other hand, had inferior performance in these tests, suggesting that they have difficulty in the tests which require greater support and use of the phonological knowledge (grapheme-phoneme correspondence). As a consequence, as they present difficulties in reading isolated low-frequency words, one can infer that they also have difficulty in undertaking lexical-semantic access, impairing their comprehension of the sentences. Such findings, relating to difficulties in decoding, have been widely described in the Brazilian and international literature on students with dyslexia (Capellini et al., 2015; Fletcher et al., 2009; Germano \& Capellini, 2011, 2015; Snowling, 2004; Vellutino et al., 1994, 1996; Vellutino \& Fletcher, 2013).

However: in relation to comparison between the sexes, one of the possible hypotheses for explaining this study's findings was described by Lambe (1999) and Pugh et al. (1996). The authors mentioned that in activities of phonological processing, female dyslexics undertake greater activation of the neuronal networks of the left hemisphere, which are responsible for phonological and lexical-semantic processing, while the same did not take place for the male dyslexics, among whom distinct connections were ascertained. As a result, the authors concluded that there is greater compensation for female students than for male students. Hence, the authors also emphasized that understanding dyslexia's neural substrates is fundamental for better characterization of the population, promoting the undertaking of differential diagnoses and interventional planning.

In the present study, although this was not part of its objective, as this laboratory receives referrals of students from the public and municipal network, providing diagnostic tests across the region, it is highlighted that there were more male students than female. This data is in accordance with the findings of the international literature (Hawke et al., 2009), in which emphasis is placed on the higher number of male students with reading problems, although the proportion between male and female students with reading difficulties varies broadly. According to these authors, there are various biological and environmental hypotheses proposed for explaining the gender differences in rates of prevalence (Geschwind, 1981; Liederman et al., 2005; Nass, 1993; Symmes \& Rapoport, 1972; Tallal \& Fitch, 1993).

In the present study, however, the dyslexic students presented low performance in tests of their reading and reading comprehension. When compared by sex, only two tests presented evidence of difference. The difference by sex was not found in the PROLEC standardization study (Capellini et al., 2012), the scores being similar for girls and boys. The differences found were between the school years, given that as the school years pass, reading improves.

It is necessary, all the same, to stress this study's limitations, which lie in the fact that there was no possibility for pairing the sample by sex. This limitation, however, has also been verified in international studies, which emphasized the prevalence of males in comparison with females.

This study's findings evidenced difference in performance in reading and in reading comprehension by sex among Brazilian students with dyslexia only in two tests: reading of lowfrequency words and comprehension. As a result, it is concluded that discussing the difference between students with dyslexia by sex may be relevant, in both the educational and clinical contexts, as among the five variables studied, two provided sufficient information for promoting greater discussion on the topic, highlighting the importance of further studies.

\section{References}

Batista, A. O., Cunha, V. L. O., \& Germano, G. D. (2011). Relação linguagem escrita, fonologia e problemas de aprendizagem [Relation among written language, phonology and learning problems]. In S. A. Capellini, C. Silva, \& F. H. Pinheiro (Orgs.), Tópicos em transtornos de aprendizagem [Topics in learning disorders] (pp. 40-52). São José dos Campos, SP: Pulso Editorial.

Capellini, S. A., Cerqueira César, A. B. P., \& Germano, G. D. (2015). Early identification of reading problems: Preliminary study with students of 1st grade. Procedia - Social and Behavioral Sciences, 174, 1351-1355. doi:10.1016/j.sbspro.2015.01.758

Capellini, S. A., Oliveira, A. M., \& Cuetos, F. (Orgs.). (2012). PROLEC: Provas de avaliação dos processos de leitura [PROLEC: Reading processes assessment] (2a ed.). São Paulo, SP: Casa do Psicólogo. 
Cunha, V. L. O., \& Capellini, S. A. (2009). Desempenho de escolares de $1^{\mathrm{a}}$ a $4^{\mathrm{a}}$ série do ensino fundamental nas provas de habilidades metafonológicas e de leitura - PROHMELE [Performance of elementary school students from 1st to 4th grades at the metalinguistics skills and reading proof - PROHMELE]. Revista da Sociedade Brasileira de Fonoaudiologia, 14(1), 56-68. doi:10.1590/S151680342009000100011

Cunha, V.L. O., \& Capellini, S.A. (2010). Análise psicolinguística e cognitivo-linguística das provas de habilidades metalinguísticas e leitura realizada em escolares de $2^{\mathrm{a}}$ a $5^{\mathrm{a}}$ série [Psycholinguistic and cognitive-linguistic analysis of the metalinguistic skills and reading proofs in students from 2nd to 5th grades of elementary education]. Revista CEFAC, 12(5), 772-783. doi:10.1590/S1516-18462010005000017

DeFries, J. C., \& Gillis, J. J. (1993). Genetics of reading disabilities. In R. Plomin \& G. E. McClearn (Eds.), Nature, nurture and psychology (pp. 121-145). Washington, DC: American Psychological Association.

Desroches, A. S., Joanisse, M. F., \& Robertson, E. K. (2006). Specific phonological impairments in dyslexia revealed by eye tracking. Cognition, 100(3), B32-B42. doi:10.1016/j. cognition.2005.09.001

Donfrancesco, R., Iozzino, R., Caruso, B., Ferrante, L., Mugnaini, D., Talamo, A., ... Masi, G. (2010). Is season of birth related to developmental dyslexia? Annals of Dyslexia, 60(2), 175-182. doi:10.1007/s11881-010-0037-6

Ellis, A. W., \& Young, A. W. (1988). Human cognitive neuropsychology. Hove, United Kingdom: Erlbaum.

Finucci, J. M., \& Childs, B. (1981). Are there really more dyslexic boys than girls? In A. Ansara, N. Geschwind, A. M. Galaburda, M. Albert, \& N. Gartrell (Eds.), Sex differences in dyslexia (pp. 1-9). Towson, MD: Orton Dyslexia Society.

Fletcher, J. M., Lyons, G. R., Fuchs, L. S., \& Barnes, M. A. (2009). Transtornos de aprendizagem: Da identificação à intervenção [Learning disabilities: From identification to intervention] (R. C. Costa, Trad.). Porto Alegre, RS: Artmed.

Galaburda, A. M., \& Kemper, T. L. (1979). Cytoarchitectonic abnormalities in developmental dyslexia: A case study. Annals of Neurology, 6(2), 94-100. doi:10.1002/ ana.410060203

Germano, G. D., \& Capellini, S. A. (2008). Eficácia do programa de remediação auditivo-visual computadorizado em escolares com dislexia [Efficacy of an audio-visual computerized remediation program in students with dyslexia]. Pró-Fono: Revista de Atualização Científica, 20(4), 237-242. doi:10.1590/S0104-56872008000400006

Germano, G. D., \& Capellini, S. A. (2011). Desempenho de escolares com dislexia, transtornos e dificuldades de aprendizagem em provas de habilidades metafonológicas (PROHFON) [Performance of students with dyslexia, learning disabilities and learning difficulties in metaphonological abilities tests (PROHFON)]. Jornal da
Sociedade Brasileira de Fonoaudiologia, 23(2), 135-141. doi:10.1590/S2179-64912011000200010

Germano, G. D., \& Capellini, S. A. (2015). Avaliação das habilidades metafonológicas (PROHFON): Caracterização e comparação do desempenho em escolares [Metalinguistic skills evaluation (PROHFON): Characterization and comparison of students' performance]. Psicologia: Reflexão e Crítica, 28(2), 378-387. doi:10.1590/1678-7153.201528218

Germano, G. D., Pinheiro, F. H., \& Cunha, V. L. O. (2010). Avaliação e intervenção nas habilidades metalinguísticas [Assessment and intervention in the metalinguistic skills]. In S. A. Capellini, G. D. Germano, \& V. L. O. Cunha (Orgs.), Transtornos de aprendizagem e transtornos da atenção: Da avaliação à intervenção [Learning and attention disorder: Assessment to intervention] (pp. 3548). São José dos Campos, SP: Pulso Editorial.

Geschwind, N. (1981). A reaction to the conference on sex differences in dyslexia. In A. Ansara, N. Geschwind, A. M. Galaburda, M. Albert, \& N. Gartrell (Eds.), Sex differences in dyslexia (pp. xiii-xviii). Towson, MD: Orton Dyslexia Society.

Harlaar, N., Spinath, F., Dale, P., \& Plomin, R. (2005). Genetic influences on early word recognition abilities and disabilities: A study of 7-year-old twins. Journal of Child Psychology and Psychiatry, 46(4), 373-384. doi:10.1111/ j.1469-7610.2004.00358.x

Hatcher, J., Snowling, M. J., \& Griffiths, Y. M. (2002). Cognitive assessment of dyslexic students in higher education. British Journal of Educational Psychology, 72(Pt 1), 119-133. doi:10.1348/000709902158801

Hawke, J. L., Olson, R. K., Willcut, E. G., Wadsworth, S. J., \& DeFries, J. C. (2009). Gender ratios for reading difficulties. Dyslexia, 15(3), 239-242. doi:10.1002/dys.389

Kim, Y.-S., Petscher, Y., Foorman, B. R., \& Zhou, C. (2010). The contributions of phonological awareness and letter-name knowledge to letter sound acquisition - a cross-classified multilevel model approach. Journal of Educational Psychology, 102(2), 313-326. doi:10.1037/a0018449

Lambe, E. K. (1999). Dyslexia, gender, and brain imaging. Neuropsychologia, 37(5), 521-536. doi:10.1016/S00283932(98)00146-8

Leach, J. M., Scarborough, H. S., \& Rescorla, L. (2003). Lateemerging reading disabilities. Journal of Educational Psychology, 95(2), 211-224. doi:10.1037/0022-0663.95.2.211

Liederman, J., Kantrowitz, L., \& Flannery, K. (2005). Male vulnerability to reading disability is not likely to be a myth: A call for new data. Journal of Learning Disabilities, 38(2), 109-129. doi:10.1177/00222194050380020201

Lukasova, K., Barbosa, A. C. C., \& Macedo, E. C. (2009). Discriminação fonológica e memória em crianças com dislexia e bons leitores [Phonological discrimination and memory in children with dyslexia and good readers]. PsicoUSF, 14(1), 1-9. doi:10.1590/S1413-82712009000100002 
Nass, R. D. (1993). Sex differences in learning abilities and disabilities. Annals of Dyslexia, 43(1), 61-77. doi:10.1007/ BF02928174

Nation, K., \& Cocksey, J. (2009). The relationship between knowing a word and reading it aloud in children's word reading development. Journal of Experimental Child Psychology, 103(3), 296-308. doi:10.1016/j.jecp.2009.03.004

O'Connor, R. E., Swanson, H. L., \& Geraghty, C. (2010). Improvement in reading rate under independent and difficult text levels: Influences on word and comprehension skills. Journal of Educational Psychology, 102(1), 1-19. doi: $10.1037 / \mathrm{a} 0017488$

Oliveira, A. M., Cardoso, M. H., \& Capellini, S. A. (2012). Caracterização dos processos de leitura em escolares com dislexia e distúrbio de aprendizagem [Characterization of reading processes in students with dyslexia and learning disabilities]. Revista da Sociedade Brasileira de Fonoaudiologia, 17(2), 201-207. doi:10.1590/S151680342012000200017

Peterson, R. L., Pennington, B. F., Olson, R. K., \& Wadsworth, S. J. (2014). Longitudinal stability of phonological and surface subtypes of developmental dyslexia. Scientific Studies of Reading, 18(5), 347-362. doi:10.1080/108884 38.2014 .904870

Piasta, S. B., \& Wagner, R. K. (2010). Learning letter names and sounds: Effects of instruction, letter type, and phonological processing skill. Journal of Experimental Child Psychology, 105(4), 324-344. doi:10.1016/j. jecp.2009.12.008

Pinheiro, A. M. V. (2006). Leitura e escrita: Uma abordagem cognitiva [Reading and writing: A cognitive approach] (2a ed.). Campinas, SP: Livro Pleno.

Pinheiro, A. M. V., Lúcio, P. S., \& Silva, D. M. R. (2008). Avaliação cognitiva de leitura: $\mathrm{O}$ efeito de regularidade grafema-fonema e fonema-grafema na leitura em voz alta de palavras isoladas no português do Brasil [Cognitive reading evaluation: The grapheme-phoneme and the phonemegrapheme regularity effect in the word reading aloud in brazilian portuguese]. Psicologia: Teoria $e$ Prática, 10(2), 16-30. Retrieved from http://editorarevistas. mackenzie.br/index.php/ptp/article/view/464/279

Pugh, K. R., Shaywitz, B. A., Shaywitz, S. E., Constable, R. T., Skudlarski, P., Fulbright, R. K., ... Gore, J. C. (1996). Cerebral organization of component processes in reading. Brain, 119(Pt 4), 1221-1238. doi:10.1093/brain/119.4.1221

Snowling, M. J. (2004). Dislexia [Dyslexia] (M. L. Giannini, Trad., 2a ed.). São Paulo, SP: Livraria Santos Editora.

Stevenson, J. (1992). Identifying sex differences in reading disability: Lessons from a twin study. Reading and Writing, 4(4), 307-326. doi:10.1007/BF01027711

Symmes, J. S., \& Rapoport, J. L. (1972). Unexpected reading failure. American Journal of Orthopsychiatry, 42(1), 8291. doi:10.1111/j.1939-0025.1972.tb02474.x
Tallal, P., \& Fitch, R. H. (1993). Hormones and cerebral organization: Implications for the development and transmission of language and learning disabilities. In A. M. Galaburda (Ed.), Dyslexia and development: Neurobiological aspects of extra-ordinary brains (pp. 168-186). Cambridge, MA: Harvard University Press.

Vellutino, F. R., \& Fletcher, J. M. (2013). Dislexia do desenvolvimento [Developmental dyslexia]. In M. J. Snowling \& C. Hulme (Eds.), A ciência da leitura [The Science of reading: A handbook] (R. C. Costa, Trad., pp. 380-396). Porto Alegre, RS: Penso.

Vellutino, F. R., Scanlon, D. M., \& Tanzman, M. S. (1994). Components of reading ability: Issues and problems in operationalizing word identification, phonological coding, and orthographic coding. In G. R. Lyon (Ed.). Frames of reference for the assessment of learning disabilities: New views on measurement issues (pp. 279-332). Baltimore, MD: Brookes.

Vellutino, F. R., Scanlon, D. M., Sipay, E. R., Small, S. G., Chen, R., Pratt, A., \& Denckla, M. B. (1996). Cognitive profiles of difficult - to-remediate and readily - remediate poor readers: Early interventions as a vehicle for distinguishing between cognitive and experimental deficits as basic cause of specific reading disability. Journal of Educational Psychology, 88(4), 601-638. doi:10.1037//0022-0663.88.4.601

Veuillet, E., Magnan, A., Ecalle, J., Thai-Van, H., \& Collet, L. (2007). Auditory processing disorder in children with reading disabilities: Effect of audiovisual training. Brain, 130 (Pt 11), 2915-2928. doi:10.1093/brain/awm235

Wong, S. W., McBride - Chang, C., Lam, C., Chan, B., Lam, F. W., \& Doo, S. (2012). The joint effects of risk status, gender, early literacy and cognitive skills on the presence of dyslexia among a group of high - risk Chinese children. Dyslexia, 18(1), 40-57. doi:10.1002/dys.1434

Adriana Marques de Oliveira is a postdoctoral researcher of the Universidade Estadual Paulista.

Giseli Donadon Germano is a Professor of the Universidade Estadual Paulista.

Simone Aparecida Capellini is a Full Professor of the Universidade Estadual Paulista.

Received: Dec. 22, 2015

1st Revision: Jun. 07, 2016

Approved: Aug. 08, 2016

How to cite this article:

Oliveira, A. M., Germano, G. D., \& Capellini, S. A. (2017). Comparison of the reading performance in students with developmental dyslexia by sex. Paidéia (Ribeirão Preto), 27(68), 306-313. doi: 10.1590/1982-43272768201708 